Danchinova G.A. ', Lyapunova N.A. ', Manzarova E.L. ', Solovarov I.S. 1, Petrova I.V. ', Lyapunov A.V. ', Bataa J. ${ }^{2}$, Khasnatinov M.A. ${ }^{1}$

\title{
PRELIMINARY RESULTS OF THE STUDY OF SUBCLINICAL INFECTIONS OF TICK-BORNE PATHOGENS IN BITTEN HUMANS
}

\author{
${ }^{1}$ Scientific Centre for Family Health and Human Reproduction Problems \\ (ul. Timiryazeva 16, Irkutsk 664003, Russian Federation) \\ ${ }^{2}$ National Center for Communicable Diseases \\ (Horoo 14, 13th district, Bayanzurkh distrct, Ulaanbaatar, Mongolia)
}

\begin{abstract}
Background. Early detection of tick-borne pathogens in blood samples of infected people prevents the disease before clinical manifestations using antibiotic and immunoglobulin treatment. As far as tick-borne diseases are associated with significant activation of innate immune response, the changes in the cytokine profile soon after a tick bite could be used as an indicator of early tick-borne infection.

Aims. The goal of this study was to characterize the production of cytokines during first 2-4 days after a tick bite in asymptomatic people infected with tick-borne pathogens.

Materials and methods. The infection of tick-borne encephalitis virus, B. burgdorferi sensu lato, A. phagocytophilum and E. chaffeensis / E. muris was detected in blood of bitten humans using appropriate commercial real time RT-PCR and ELISA assays. Concentration of 14 cytokines in plasma of 89 infected and 45 non-infected people was established using quantitative ELISA kits.

Results. Between $2^{\text {nd }}$ and $4^{\text {th }}$ days after tick bite, the prevalence and concentration of certain cytokines in blood of infected people significantly differed from those of the control group. Bacterial pathogens exhibited very similar patterns of cytokine profiles with induction of IL-1 $\alpha$, IL-8 u IFN- $\alpha$ and suppression of SOD, IL-1Ra u IL-17A. For virus infection the increased concentrations of IL-1 $\alpha, I L-8, I L-10, I L-17 A, I F N-\gamma$ and SOD were detected. The only suppressed cytokine was IL-1Ra receptor antagonist.

Conclusions. The results suggest that evaluation of innate immune response between $2^{\text {nd }}$ and $4^{\text {th }}$ days after the tick bite could be a useful tool for evaluation of the risk of tick-borne disease for the humans bitten by ticks.
\end{abstract}

Key words: tick-borne infections, tick-borne encephalitis, Lyme disease, human monocytic ehrlichiosis, human granulocytic anaplasmosis, blood, cytokines

\section{ПЕРВЫЕ РЕЗУЛЬТАТЫ ИЗУЧЕНИЯ «КЛЕЩЕВЫХ» ИНФЕКЦИЙ НА ДОКЛИНИЧЕСКОЙ СТАДИИ ИНФИЦИРОВАНИЯ ЧЕЛОВЕКА}

\author{
Данчинова Г.А. ', Пяпунова Н.А. ', Манзарова И.С. ', Соповаров И.С. ', Петрова И.В. ', \\ Пяпунов А.В. ', Батаа Ж. ${ }^{2}$, Хаснатинов М.А. ${ }^{1}$ \\ 1 ФГБНУ «Научный центр проблем здоровья семьи и репродукции человека» \\ (664003, г. Иркутск, ул. Тимирязева, 16, Россия) \\ ${ }^{2}$ Институт традиционной медицины, Монгольский национальный университет медицинских наук
} (210648, г. Улан-Батор, ул. С. Зориг, 3, Монголия)

Введение. Исследование врождённого иммунного ответа человека к клещевым инфекциям после подтверждённого факта укуса заражённым клещом на ранних, скрытых доклинических стадиях может показать реакцию организма человека и будет способствовать разработке новых способов ранней диагностики и профилактики трансмиссивных заболеваний.

Материал и методы. Всего на заражённость вирусом клещевого энцефалита, B. burgdorferi sensu lato, A. phagocytophilum и E. chaffeensis / E. тигіs проанализирован 2821 образец крови от людей, пострадавщих от присасывания иксодовых клещей. 1421 проба проанализирована на наличие антител к клещевым инфекциям. В заражённых образцах крови с помощью иммуноферментного анализа определена концентрация основных цитокинов. Результаты и обсуждение. Установлена инфицированность людей после присасываний клещей: 3,2 \% - антиген вируса клещевого энщефбалита; 1,8 \% - РНК вируса клещевого энщефалита; 4,1 \% - B. burgdorferi sensu lato; 0,45\% - A. phagocytophilum; 0,15\% - E. chaffeensis / E. тигіs. Показано, что бактериальные патогены, особенно B. burgdorferi sensu lato и A. phagocytophilum, индуцируют очень похожие профили врождённого иммунного ответа человека. Для этих микроорганизмов характерна активация IL-1 $\alpha$, IL-8 и IFN- $\alpha$ и подавление синтеза SOD, IL-1Ra и IL-17A. Инфекция ВКЭ на ранней стадии индуцирует своеобразный профиль цитокинового ответа узаражённого человека. Для вирусной инфекции характерно возрастание концентрации IL-1 $\alpha, I L-8, I L-10$, $I L-17 A$, интерферона IFN- $\gamma$ u, в отличие от бактериальных инфекций, SOD. Некоторое подавление синтеза отмечается только для рецепторного антагониста IL-1Ra.

Заключение. Показано, что иммунный ответ при клещевых инфекциях запускается сразу после заражения человека, и уже в первые 2-5 дней можно обнаружить изменения в концентрации основных цитокинов в плазме крови.

ключевые слова: клещевые инфекции, клещевой энцефалит, иксодовый клещевой боррелиоз, моноцитарный эрлихиоз человека, гранулоцитарный анаплазмоз человека, образцы крови, цитокины

Currently, viral and bacterial infections transmitted to humans by ticks are a serious health problem in many countries of Eurasia, including the Russian Federation, especially in the regions of the Siberian Federal District. An important feature of tick-borne infections is the polymorphism of clinical manifestations of the infection. However, most of the current data on the pathogenesis of tick-borne infections were obtained basing on studies of patients with severe clinical manifestations of infections. 
From the official statistical reports of the Federal Service for Supervision of Consumer Protection and Infectious and Parasitic Disease of the Russian Federation, it is known that approximately 3,000 cases of tick-borne encephalitis (TBE) and about 9,000 cases of Lyme disease (LD) are registered annually in Russia [4]. Recently two tick-borne infections less studied in our country - human granulocytic anaplasmosis and human monocytic ehrlichiosis - are recognized by physicians. The significance of tick-borne diseases is determined by possible fatalities, disability, transition to chronic form, and high cost of treatment. Tick attack rate is very high in endemic regions. Thus, in Irkutsk, the Centre for Diagnosis and Prevention of Tick-Borne Diseases (hereinafter, the Centre) of the Scientific Centre for Family Health and Human Reproduction Problems (FBSC FHHRP) reports that approximately from 6.5 to 8.0 thousands of people bitten by ixodid ticks seek treatment annually.

There is a wide variety of clinical manifestations of tick-borne infections. Thus, up to $80 \%$ of cases of TBE is followed by febrility without neurological manifestations or without any clinical symptoms at all. However, in 20-40\% a serious illness develops with the development of meningoencephalitis, and a possible chronization of the infection. The incubation period of TBE is 7-21 days, while in the 2-4 days after infection the antigen of BSE and infectious virus are detected in the blood of infected people [2, $3,14,15,16,19,20]$. During the course of TBE in humans and in model animals, stimulation of elements of the innate immune response, in particular, interferons $\alpha$ and $\beta$ (IFN- $\alpha$, IFN- $\beta$ ), interferon gamma (IFN- $\gamma$ ), tumor necrosis factor (TNF- $\beta$ ) and interleukin 6 ( IL-6) [1, 5, 23, 27].

For LD, there is also a wide variability in clinical manifestations, including feverish forms, severe damage of joints (lyme-arthritis), skin (acrodermatitis), and central nervous system (neuroborreliosis). There is a correlation between the species of $B$. burgdorferi sensu lato and the features of the course of the disease $[7,25,26]$. In patients with LD, the induction of cytokines IL-6, IL-8, IL-12, IL-18, IFN- $\gamma$, IFN- $\beta$ and CXCL13 predominates $[9,17]$.

The causative agent of HGA - A. phagocytophilum was opened in 1994. The infection is distributed across the entire territory of North America and Eurasia [10, 13, 21]. In the Russian Federation, A. phagocytophylum was detected in I. persulcatus ticks both in European [12] and in Asian [22; 24] parts of the country. Incidence of HGA has the highest rates in the US: up to 65 cases, with an average of $0.3-1.5$ cases per 100 thousands of population [6]. The immune layer among the healthy population in the United States is between 0.5 and $3.5 \%$ [18], however, ranging from 9 to $36 \%$ among the people exposed to tick bites. At the same time, most infections are asymptomatic $[6,11]$. In the immunopathogenesis of HGA, the expression of IFN $\gamma$ and IL-10 was increased, whereas the synthesis of TNF- $\beta$, IL-1 $\beta$, and IL-4 was suppressed [11]. In this case, IFN- $\gamma$ is considered one of the limiting factors of the infection [8]. In Russia, the real epidemiological significance of HGA is not completely characterized.

In the literature, we have not found any studies devoted to the complex study of the earliest stages of tick-borne infections in the humans. The closest studies describe the course of infection in patients after the emergence of a full range of clinical symptoms of the infectious process. With another approach, applied in modern science, the course of infection in model systems - laboratory animals and cell cultures - has been studied. In this regard, the aim of the study is to evaluate the course of infection and the dynamics of the immune response at the earliest, subclinical stages in individuals infected through the bite of ixodid ticks.

\section{MATERIALS AND METHODS}

The samples of plasma and the leukocyte fraction of the blood of people who attended the Centre after tick bite during 2016 were used in the work. In total, 2,281 blood samples were tested for the infection with TBEV, B. burgdorferi sensu lato, A. phagocytophilum and E. chaffeensis / E. muris and 1/421 samples were examined in ELISA for the presence of antibodies to the abovementioned infections. Three main factors affecting the course and outcomes of tickborne infections were studied: the pathogens themselves, the innate immunity of patients and the humoral immunity of patients after the bite of an infected tick. Each of these elements was examined both at the time of infection and in dynamics, which allowed to assess more fully their effect on the development of infection in the subclinical stage.

The ELISA kit “IFA TC AG TBEV” (FGUP “NPO” Microgen”, Russia, Moscow) was used to detect the antigen of TBEV in blood samples. The nucleic acids of TBEV, B. burgdorferi sensu lato, A. phagocytophilum and E. chaffeensis / E. muris were detected using the multiplex real-time PCR kit "Multiprime" (Amplisens, Moscow). To confirm the fact of human infection, positive samples were verified either in analysis of ELISA / PCR, or in PCR with primers to specific fragments of the genome of the corresponding pathogens (Table 1).

Detection of immunoglobulins IgM and IgG for TBEV, B. burgdorferi sensu lato, A. phagocytophilum and E. chaffeensis / E. muris were produced with the help of ELISA test systems VektoTBEV-IgM, VektoTBEV-IgG, LymeBest-IgM and LymeBest-IgG (Vector Best, Novosibirsk), HGA-IFA-IgM, HGA-IFA-IgG, HME-IFA-IgM and HME-IFA-IgG (OOO Omnix, St. Petersburg) according to the manufacturers' instructions.

The spectrum and balance of cytokines were assessed by ELISA test systems for quantifying the concentration of interleukins IL-1 $\alpha$, IL-1 $\beta$, IL-4, IL-8, IL-10, IL-17A, IL18 , granulocyte colony stimulating factor G-CSF, tumor necrosis factor (TNF- $\alpha$, interferon IFN- $\alpha$ and IFN- $\gamma$, superoxide dismutase SOD, and IL-1Ra interleukin-1 receptor antagonist. The test systems of 000 Tsitokin (St. Petersburg) were used, with the exception of the test system for estimating IL-18 interleukin (Vector-Best, Novosibirsk) according to the manufacturers' instructions.

The results were presented as mean values; a standard deviation of the mean values was calculated to estimate the variability of the results. To analyze the results obtained, we used standard statistical methods, such as the Shapiro - Wilk test, the Mann - Whitney U-test, the Kruskall - Wallace criterion, the Student t-test, and others.

\section{RESULTS AND DISCUSSION}

\section{Infection of people with pathogens of tick-borne infections after a tick bite}

Analysis of tick-borne pathogens in infected people showed that $3.2 \%$ of people had TBEV antigen, $1.8 \%$ had TBEV RNA, and $4.1 \%, 0.45 \%$ and $0.15 \%$ had RNA/ DNA of B. burgdorferi sensu lato, A. phagocytophilum and 
ACTA BIOMEDICA SCIENTIFICA, 2018, Tом 3, № 1

PCR primers used for amplification of genome fragments of tick-borne pathogens

\begin{tabular}{|c|c|c|c|}
\hline ID & Sequence & Organism & Fragment length, b.p \\
\hline TBEV 5`f & AGATTTTCTTGCRCGTGCRTGCGTTTGCTTCGG & \multirow{4}{*}{ TBEV } & \multirow{2}{*}{1643} \\
\hline BEV $1643 r$ & GCCAGATCATTRAACCAGTC & & \\
\hline TBEV $1255 f$ & YTCRATGGAYGTGTGGCTTGA & & \multirow{2}{*}{388} \\
\hline TBEV $1643 r$ & GCCAGATCATTRAACCAGTC & & \\
\hline 16SEhrD & GGTACCYACAGAAGAAGTCC & \multirow{2}{*}{ Ehrlichia sp. } & \multirow{2}{*}{344} \\
\hline 16SEhrR & TAGCACTCATCGTITACAGC & & \\
\hline rrs $11 f$ & GTGCGTCTTAAGCATGCAAGTCAA & \multirow{6}{*}{ B. burgdorferi sensu lato } & \multirow{2}{*}{500} \\
\hline rrs 519r & CCGAACAACGCTCGCCCCTTA & & \\
\hline OspC Cr & GTAACTGGAAAAATAAAGTCAATAT & & \multirow{2}{*}{800} \\
\hline OspC Nf & CACAAATTAATGAAAAAGAATACA & & \\
\hline RS1 & CTGCGAGTTCGCGGGAGA & & \multirow{2}{*}{250} \\
\hline RS2 & TCCTAGGCATTCACCATA & & \\
\hline GlpQF & GGTATGCTTATTGGTCTTC & \multirow{2}{*}{ B. miyamotoi [28] } & \multirow{2}{*}{340} \\
\hline GlpQR & TTGTATCCTCTTGTAATTG & & \\
\hline Ap-3761F & CTGCTCTKGCCAARACCTC & \multirow{4}{*}{ A. phagocytophilum } & \multirow{2}{*}{-400} \\
\hline Ap-4183R & CAATAGTYTTAGCTAGTAACC & & \\
\hline ApF 1 & TCCTGGCTCAGAACGAACG & & \multirow{2}{*}{1461} \\
\hline ApR1 & CCTACAGCTACCTTGTTACG & & \\
\hline
\end{tabular}

E. chaffeensis / E. muris, respectively. Analysis of human blood samples for the presence of antibodies to tick-borne pathogens revealed the presence of IgM antibodies to the agents of the TBE, Lyme disease, HME and HGA in $16 \%$, $10 \%, 14 \%$ and $11 \%$ of samples, respectively. IgG antibodies to these infections were detected in $4.8 \%, 30 \%$, $12 \%$ and $6 \%$ of the population. Interestingly, in 85 cases $(\sim 2 \%$ of the affected), none of the trivial causative agents of tick-borne infections was detected, as were the antibodies to them. However, these patients developed obvious health disorders after the tick bite.

Based on the data obtained, a group of people with positive samples (hereinafter "test group", 89 people) and a control group (45 people) were formed. These groups were used for further study of tick infections at the preclinical stage. In particular, the tests confirming the fact of infection, the characteristics of the genetic diversity of microorganisms, analyses of humoral and innate immunity were conducted. Independent confirmation of infection was obtained for 58 samples (65 \%) from the test group. All samples from the control group had significantly negative results on TBEV, B. burgdorferi sensu lato, B. miyamotoi, A. phagocytophilum or E. chaffeensis / E. muris.

Human humoral immune response at the preclinical stage of the infection

Analysis of the humoral immune response in the test group showed that after the prevention of tick infections, 10 out of 58 people still produced antibodies to causative agents of TBEV ( 6 cases) or Lyme disease (4 cases). The dynamics of the humoral immune response in all cases corresponded to the previously described data. IgM antibodies were detected at 11-23 days after infection, while the production of IgG antibodies occurred at later stages of infection (30-51 days after the tick bite). There were no antibodies detected to the agents of HME or HGA. No antibodies were detected at the earliest stages of infection at 2-11 days after the tick bite as well. This indicates that none of the people surveyed in the foreseeable past was infected with TBEV, B. burgdorferi sensu lato, A. phagocytophilum, or E. chaffeensis / E. muris. Thus, it can be assumed that all observed responses of the human body are associated with the investigated case of infection, and not with previous contacts of the infected people with any of these pathogens.

Innate immune response in humans

at the preclinical stage of the infection

Analysis of the spectrum of cytokines present in the blood of uninfected people showed that all the cytokines in the control group are present. However, the occurrence of each of them varied greatly. For example, interleukin IL-1 $\beta$ was found in only $3 \%$ of persons affected by the bite of an infected tick, IL-1R receptor antagonist IL-1R - in $17 \%$, whereas such cytokines as IFN- $\alpha$, IFN- $\gamma$ and SOD were expressed in all the examined people from the control group. A detailed description of the cytokine profiles of the control and test groups is given in Table 2 .

In humans infected with TBEV at an early stage of infection, virtually all cytokines are also found, with the exception of IL-1 $\beta$, which was not detected. However, the occurrence of some of them is significantly different in comparison with the control group. For example, IL-6 (in $77 \%$ of people infected with TBEV, compared to 47 of the control group), IL-17A, IL-18 and IL-1Ra are significantly more often detected in blood samples from infected humans (Table 2). At the same time, IL- $1 \alpha$ is less common in the test group than in the control group (30 \% vs. $53 \%$ ).

For B. burgdorferi sensu lato infection, the overall spectrum of cytokines is similar to that of a subset of people infected with TBEV, but among these patients no expression of 
Occurrence of different cytokines in people infected with TBEV, B. burgdorferi s.I., and in control group (uninfected people)

\begin{tabular}{|l|c|c|c|c|c|c|c|c|c|c|c|c|c|c|}
\hline & $\begin{array}{c}\text { IL- } \\
\text { lalpha }\end{array}$ & $\begin{array}{c}\text { IL- } \\
\text { 1beta }\end{array}$ & IL-4 & IL-6 & IL-8 & IL-10 & IL-17A & IL-18 & G-CSF & $\begin{array}{c}\text { TNF- } \\
\text { alpha }\end{array}$ & $\begin{array}{c}\text { IFN- } \\
\text { alpha }\end{array}$ & $\begin{array}{c}\text { IFN- } \\
\text { gamma }\end{array}$ & SOD & IL-1Ra \\
\hline TBEV-infected, \% & 30 & 0 & 48,5 & 77 & 70 & 76 & 30 & 54,5 & 82 & 42 & 100 & 100 & 100 & 37 \\
\hline $\begin{array}{l}\text { B. burgdorferi s.I.- } \\
\text { infected, \% }\end{array}$ & 100 & 0 & 50 & 100 & 100 & 75 & 0 & 50 & 50 & 25 & 100 & 100 & 100 & 0 \\
\hline Control group, \% & 53 & 3 & 53 & 47 & 80 & 78 & 5,5 & 30,5 & 72 & 42 & 100 & 100 & 100 & 17 \\
\hline
\end{tabular}
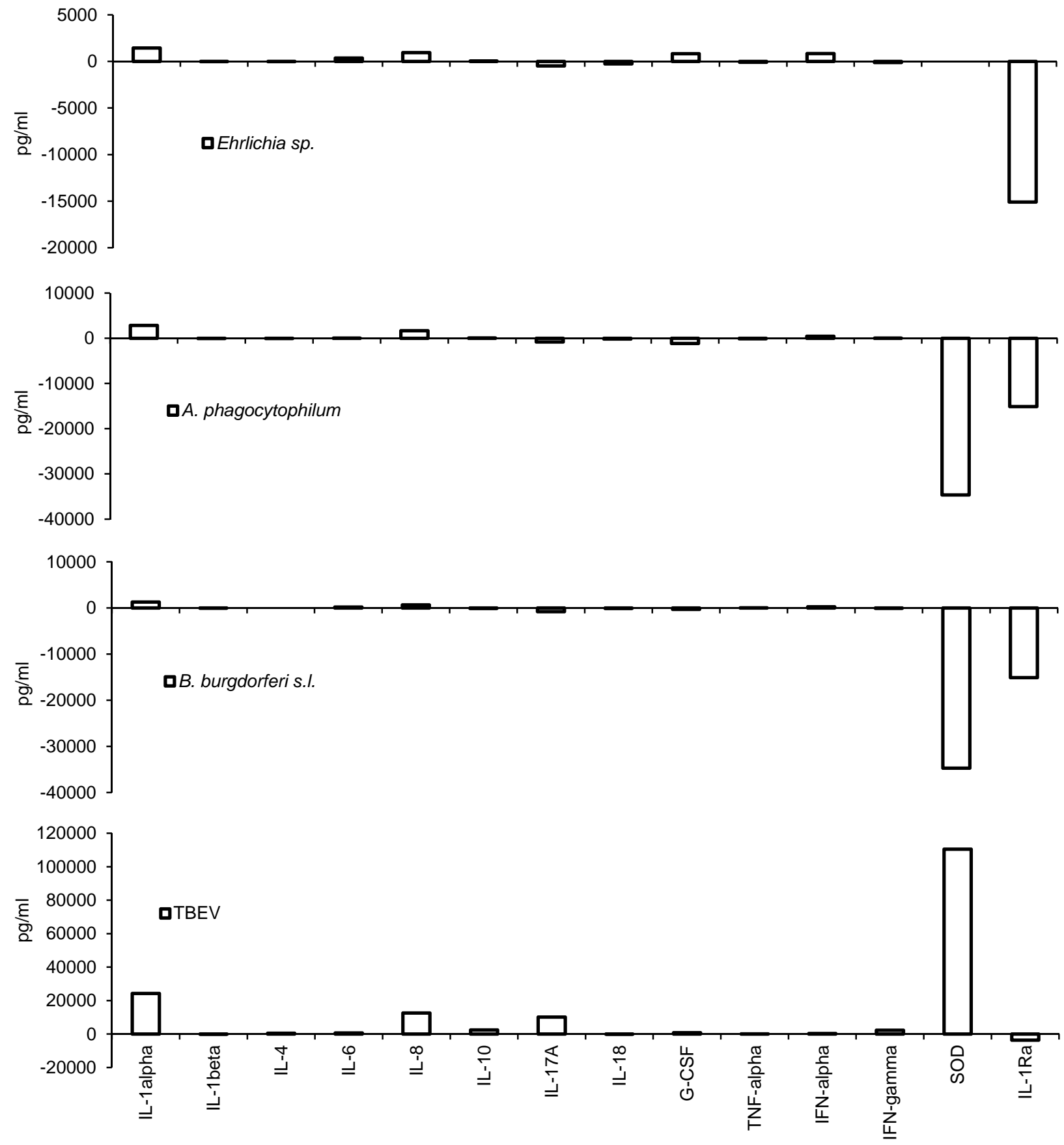

Fig. 1. Changes in cytokine levels after the infection with different tick-borne pathogens at subclinical stage of infection. The changes in comparison to control group (uninfected people) are shown.

the IL-1Ra receptor antagonist has been found. There was a significant increase in the proportion of people with interleukins IL- $1 \alpha$, IL- 6 and IL-18. At the same time, the proportion of patients with G-CSF and TNF- $\alpha$ present in the blood is slightly reduced relative to the control group (Table 2).
For confirmed cases of human infection by A. phagocytophilum and E. chaffeensis / E. muris, the quantitative characteristics of expression of the components of the innate immune response is given. 
When considering the quantitative characteristics of the innate immune response in the studied groups, it turned out that in all cases, the data obtained within the samples are characterized by high variability. However, even in this case, there are significant differences in the levels of cytokine expression in the groups of infected and uninfected patients (Fig. 1).

Thus, in TBEV infection, an increase in the concentration of IL- $1 \alpha$, IL-8, IL-10, IL-17A and interferon IFN- $\gamma$ can be noted. Some inhibition of synthesis is noted for the IL-1Ra receptor antagonist. The greatest changes are observed in the level of SOD expression, the concentration of which increases almost threefold (from 61,000 to $172,000 \mathrm{pg} / \mathrm{ml}$ ). The infection of B. burgdorferi sensu lato, on the contrary, leads to inhibition of SOD synthesis as well as IL-1Ra, while the concentration of IL- $1 \alpha$ slightly increases. There is also a decrease in the expression level of IL-17A and G-CSF. The cytokine profile in infection with A. phagocytophilum is generally similar to that of B. burgdorferi sensu lato, except for a slight increase in the concentration of IL- 8 and interferon IFN- $\alpha$. Infection with Ehrlichia sp. is also accompanied by suppression of IL-1Ra, but the SOD level remains unchanged. As with the other two bacterial infections, the concentration of IL- $1 \alpha$, IL-8 and IFN- $\alpha$ increases, and the synthesis of IL-17A is suppressed. However, in contrast to B. burgdorferi sensu lato and $A$. phagocytophilum, a slight increase in this index is observed instead of decreasing the concentration of G-CSF.

\section{CONCLUSION}

For the first time, a number of fundamental features of tick-borne infections were revealed, which must be taken into account when improving the measures of urgent diagnostics and prevention of tick-borne diseases. We found that only $65 \%$ of cases of human infection with TBEV, B. burgdorferi sensu lato, A. phagocytophilum and E. chaffeensis / E. muris is confirmed by an independent method. This may indicate the overdiagnosis of microorganisms in the screening test, for example, due to nonspecific reactions, especially when detecting an antigen of TBEV in plasma and human serum. The detection of specific antibodies to tick-borne pathogens after the prevention procedures (within 96 hours after sucking of an infected tick) indicates an important process of triggering an immune response in humans in the early stages of the preclinical stage. In our opinion, this is a sign of the active role of elements of innate immunity which are activated within a few hours after the infection event.

When assessing the cytokine profile of infected people at the preclinical stage, a number of fundamental features of the course of infection were revealed. Thus, it has been shown that bacterial pathogens, especially $B$. burgdorferi sensu lato and A. phagocytophilum induce very similar profiles of the innate human immune response. These microorganisms are characterized by activation of IL-1 $\alpha$, IL- 8 and IFN- $\alpha$ and suppression of the synthesis of SOD, IL-1Ra and IL-17A. Infection of BSE at an early stage induces a peculiar profile of the cytokine response in an infected person. A viral infection is characterized by an increase in the concentration of IL- $1 \alpha$, IL-8, IL-10, IL-17A, interferon IFN- $\gamma$ and, in contrast to bacterial infections, SOD. Some suppression of synthesis is noted only for the receptor antagonist IL-1Ra.
Thus, we showed that the immune response is triggered immediately after human infection, and already on the second or fifth day, changes in the expression levels of the main cytokines can be detected. The data obtained suggest that the evaluation of the intensity of the innate immune response after the bite of an infected tick can significantly increase the accuracy of the risk assessment of human infection with tick infections.

The study was carried out using the equipment of the Center for Collective Use "PCR-Diagnostics" of the FBSC FHHRP.

\section{REFERENCES}

1. Бедарева Т.Ю., Попонникова Т.В., Вахраммева Т.Н. Изменения цитокинового статуса и уровня антимикробных пептидов при клещевых нейроинфекциях у детей // Сибирский медицинский журнал (Иркутск). - 2008. - Т. 82, № 7. - С. 22-25.

Bedareva TYu, Poponnikova TV, Vakhrammeva TN. (2008). Changes in the cytokine status and the level of antimicrobial peptides in tick-borne neuronectasia in children [Izmeneniya tsitokinovogo statusa i urovnya antimikrobnykh peptidov pri kleshchevykh neyroinfektsiyakh u detey]. Sibirskiy meditsinskiy zhurnal (Irkutsk), 82 (7), 22-25.

2. Вотяков В.И., Злобин В.И., Мишаева Н.П. Клещевые энцефалиты Евразии. - Новосибирск: Наука, 2002. - 437 c.

Votyakov VI, Zlobin VI, Mishaeva NP. (2002). Tickborne encephalitis of Eurasia [Kleshchevye entsefality Evrazii]. Novosibirsk, 437 p.

3. Леонова Г.Н., Беликов С.И., Павленко Е.В., Кулакова Н.В., Крылова Н.В. Биологическая и молекулярно-генетическая характеристика дальневосточной популяции вируса клещевого энцефалита и её патогенетическое значение // Вопросы вирусологии. 2007. - T. 52, № 6. - C. 13-17.

Leonova GN, Belikov SI, Pavlenko EV, Kulakova NV, Krylova NV. (2007). Biological and molecular-genetic characteristics of the Far Eastern population of tick-borne encephalitis virus and its pathogenetic significance [Biologicheskaya i molekulyarno-geneticheskaya kharakteristika dal'nevostochnoy populyatsii virusa kleshchevogo entsefalita i ee patogeneticheskoe znachenie]. Voprosy virusologii, 52 (6), 13-17.

4. Федеральная служба в сфере защиты прав потребителей и благополучия человека. Статистическая форма отчетности № 1, 2 «Инфекционная и паразитарная заболеваемость населения Российской Федерации» [Электронный ресурс]. - Режим доступа: http:// rospotrebnadzor.ru/ (дата обращения 10.10.2017).

Federal Service on Customers' Rights Protection and Human Well-Being Surveillance. (2017). Statistical reporting form № 1, 2 «Infectious and parasitic disease of the population of the Russian Federation» [Statisticheskaya forma otchetnosti № 1, 2 «Infektsionnaya i parazitarnaya zabolevayemost' naseleniya Rossiyskoy Federatsii»]. Available at: http://rospotrebnadzor.ru/ (date of access 10.10.2017).

5. Atrasheuskaya AV, Fredeking TM, Ignatyev GM. (2003). Changes in immune parameters and their correction in human cases of tick-borne encephalitis. Clin Exp Immunol, 131 (1), 148-154. 
6. Bakken JS, Dumler S. (2008). Human granulocytic anaplasmosis. Infect Dis Clin North Am, 22 (3), 433-448.

7. Biesiada G, Czepiel J, Leśniak MR, Garlicki A, Mach T. (2012). Lyme disease: review. Arch Med Sci, 8 (6), 978-82.

8. Bussmeyer U, Sarkar A, Broszat K, Lüdemann T, Möller S, van Zandbergen G, Bogdan C, Behnen M, Dumler JS, von Loewenich FD, Solbach W, Laskay T. (2010). Impairment of gamma interferon signaling in human neutrophils infected with Anaplasma phagocytophilum. Infect Immun, 78 (1), 358-363.

9. Cerar T, Ogrinc K, Lotrič-Furlan S, Kobal J, Levičnik-Stezinar S, Strle F, Ružić-Sabljić E. (2013). Diagnostic value of cytokines and chemokines in lyme neuroborreliosis. Clin Vaccine Immunol, 20 (10), 1578-1584.

10. Cochez C, Ducoffre G, Vandenvelde C, Luyasu V, Heyman P. (2011). Human anaplasmosis in Belgium: a 10-year seroepidemiological study. Ticks Tick Borne Dis, 2 (3), 156-159.

11. Dumler JS, Choi KS, Garcia-Garcia JC, Barat NS, Scorpio DG, Garyu JW, Grab DJ, Bakken JS. (2005). Human granulocytic anaplasmosis and Anaplasma Phagocytophilum Emerg Infect Dis, 11 (12), 1828-1834.

12. Eremeeva ME, Oliveira A, Moriarity J, Robinson JB, Tokarevich NK, Antyukova LP, Pyanyh VA, Emeljanova ON, Ignatjeva VN, Buzinov R, Pyankova V, Dasch GA. (2007). Detection and identification of bacterial agents in Ixodes persulcatus Schulze ticks from the north western region of Russia. Vector Borne Zoonotic Dis, 7 (3), 426-436.

13. Goodman JL, Nelson C, Vitale B, Madigan JE, Dumler JS, Kurtti TJ, Munderloh UG. (1996). Direct cultivation of the causative agent of human granulocytic ehrlichiosis. N Engl J Med, 334 (4), 209-215.

14. Gritsun TS, Lashkevich VA, Gould EA. (2003a). Tick-borne encephalitis. Antiviral Res, 57, 129-146.

15. Gritsun TS, Nuttall PA, Gould EA. (2003b). Tickborne flaviviruses. Adv Virus Res, 61, 317-371.

16. Heinz FX, Collett MS, Purcell RH, Gould EA, Howard CR, Houghton M, Moormann RJ, Rice CM, Thiel HJ. (2000). Family Flaviviridae. Virus Taxonomy. Seventh Report of the International Committee on Taxonomy of Viruses. San Diego, 859-878.

17. Krupna-Gaylord MA, Liveris D, Love AC, Wormser GP, Schwartz I, Petzke MM. (2014). Induction of type I and type III interferons by Borrelia burgdorferi correlates with pathogenesis and requires linear plasmid 36. PLoS One, 9 (6), e100174.

18. Leiby DA, Chung AP, Cable RG, Trouern-Trend J, McCullough J, Homer MJ, Reynolds LD, Houghton RL, Lodes MJ, Persing DH. (2002). Relationship between tick bites and the seroprevalence of Babesia microti and Anaplasma phagocytophila (previously Ehrlichia sp.) in blood donors. Transfusion, 42, 1585-1591.

19. Lindquist L, Vapalahti O. (2008). Tick-borne encephalitis. Lancet, 371 (9627), 1861-1871.

20. Mansfield KL, Johnson N, Phipps LP, Stephenson JR, Fooks AR, Solomon T. (2009). Tick-borne encephalitis virus - a review of an emerging zoonosis. J Gen Virol, 90 (8), 1781-1794.

21. Pusterla N, Weber R, Wolfensberger C, Schär G, Zbinden R, Fierz W, Madigan JE, Dumler JS, Lutz H. (1998). Serological evidence of human granulocytic ehrlichiosis in Switzerland. Eur J Clin Microbiol Infect Dis, 17 (3), 207-209.

22. Rar VA, Fomenko NV, Dobrotvorsky AK, Livanova NN, Rudakova SA, Fedorov EG, Astanin VB, Morozova OV. (2005). Tick-borne pathogen detection, estern Siberia, Russia. Emerg Infect Dis, 11, 1708-1715.

23. Ruzek D, Salat J, Singh SK, Kopecky J. (2011). Breakdown of the blood-brain barrier during tick-borne encephalitis in mice is not dependent on CD8+ T-cells. PLoS One, 6 (5), e20472.

24. Shpynov S, Fournier PE, Rudakov N, Tarasevich I, Raoult D. (2006). Detection of members of the genera Rickettsia, Anaplasma, and Ehrlichia in ticks collected in the Asiatic part of Russia. Ann New York Acad Sci, 1078, 378-383.

25. Stanek G, Strle F. (2003). Lyme borreliosis. Lancet, $362,1639-1647$.

26. Stanek G, Wormser GP, Gray J, Strle F. (2011). Lyme borreliosis. Lancet, 379, 461-473.

27. Stoltz M, Sundstrum KB, Hidmark E, Tolf C, Vene S, Ahlm C, Lindberg AM, Lundkvist E, Klingström J. (2011). A model system for in vitro studies of bank vole borne viruses. PLoS One, 6 (12), e28992.

28. Takano A, Goka K, Une Y, Shimada Y, Fujita H, Shiino T, Watanabe H, Kawabata H. (2010). Isolation and characterization of a novel Borrelia group of tick-borne Borreliae from imported reptiles and their associated ticks. Environ Microbiol, 12, 134-146.

\section{Information about the authors}

Danchinova Galina Anatolyevna - Doctor of Medical Sciences, Head of the Laboratory of Arthropod-Borne Infections, Scientific Centre for Family Health and Human Reproduction Problems (664003, Irkutsk, ul. Timiryazeva, 16; tel. (3952) 33-39-71; e-mail: dan-chin@yandex.ru)

Lyapunova (Bolotova) Natalie Andreevna - Junior Research Officer at the Laboratory of Arthropod-Borne Infections, Scientific Centre for Family Health and Human Reproduction Problems (e-mail: nataly2193@mail.ru) (1) http://orcid.org/0000-0001-6039-0854 Manzarova Ellina Lopsonovna - Clinical Research Assistant at the Laboratory of Arthropod-Borne Infections, Scientific Centre for Family Health and Human Reproduction Problems (e-mail: manzarova89@yandex.ru) (0) https://orcid.org/0000-0002-3891-7661 Solovarov Innokentiy Sergeevich - Junior Research Officer at the Laboratory of Arthropod-Borne Infections, Scientific Centre for Family Health and Human Reproduction Problems (e-mail: keschass@mail.ru) (1) http://orcid.org/0000-0001-9936-5330

Petrova Irina Viktorovna - Head of the Allergology Department, Scientific Centre for Family Health and Human Reproduction Problems (tel. (3952) 24-03-51; e-mail: irina petrova 62@list.ru)

Lyapunov Alexander Valeryevich - Candidate of Biological Sciences, Senior Research Officer at the Laboratory of Arthropod-Borne Infections, Scientific Centre for Family Health and Human Reproduction Problems (e-mail: liapunov.asp@mail.ru) (1) http://orcid. org/0000-0002-6947-5771

Jantsandoo Bataa - PhD, MD, Medical Advisor, The National Centre for Communicable Disease (NCCD Campus) (Mongolia, Ulaanbaatar, Bayanzurkh distrct, 13th district, Horoo, 14; tel. (976) 940-721-17; e-mail: janbataa@yandex.ru)

Khasnatinov Maxim Anatolyevich - Candidate of Biological Sciences, Leading Research Officer at the Laboratory of Arthropod-Borne Infections, Scientific Centre for Family Health and Human Reproduction Problems (e-mail: khasnatinov@yandex.ru) (1) http://orcid.org/0000-0002-8441-3640 